\title{
Prediction of Future Land Use and Land Cover (LULC) in Makassar City
}

\author{
Sudirman Nganro ${ }^{1 *}$, Slamet Trisutomo², Roland A. Barkey ${ }^{3}$, Mukti Ali², Hidefumi Imura4 \\ Akio Onishi ${ }^{4}$, Pei-I Tsai ${ }^{4}$, Mohd Amirul Mahamud 5
}

Received: $16^{\text {th }}$ June $2020 \quad$ Accepted: $5^{\text {th }}$ October 2020

\begin{abstract}
Abstrak: Migration from rural area to urban area increases urban population. It increases and needs for settlements, leading to conversion of agricultural lands into settlement areas. Inconsistent land use compared with spatial planning causes change in land use. Spatial land use expansion can be monitored and predicted by modeling. NetLogo application is a software integrated with AgentBased Modeling (ABM), which can be used to predict change of land use with various complex parameters. The present study used population growth as a parameter to predict change of land use of Makassar in 2050 based on 2017 land use classification map as the start of the prediction. The analysis result showed that the biggest change of land use happens to Settlement class which is 594.74 hectares and the smallest is Water Body class which is 8.76 hectares.
\end{abstract}

Kata kunci: Prediction, land use land cover, agent-based models, Makassar City

\section{INTRODUCTION}

Migration of people from rural to urban areas causes an increase in population and urbanization (Zope, Eldho, 2016). Changes of land use and land cover happen due to conversion of agricultural lands into settlement areas, indicating inconsistent land use compared with spatial planning (Kurnianti, Rustiadi, 2016). Spatial land use expansion can be monitored and predicted by modeling (Wijaya, 2013).

NetLogo is one of the tools which can be used to build Agent-Based Modeling (Bata, 2012)-based simulation . Agent-based modeling is a way to model the dynamics of complex systems and complex adaptive systems. Such systems are often self-organize and create emergent order. Agent-based models also include models of behavior (human or otherwise) and are used to observe the collective effects of agent behaviors and interactions (MacAl \& North, 2010).

The present study aimed to predict land use and land cover in 2050 using image interpretation data of 2017 which consists of 5 (five) land use classes, i.e. Business, Settlement, Agriculture, Forest and Water Body. The resulting land use and land cover map was used to calculate surface flow coefficient of the research object.

\footnotetext{
${ }^{1}$ Departemen Arsitektur, Fakultas Teknik, Universitas Hasanuddin

${ }^{2}$ Labo. Pengembangan Kawasan Tepian Air, Fakultas Teknik, Universitas Hasanuddin

${ }^{3}$ Labo. Perenc. dan Sistem Informasi Kehutanan, Fakultas Kehutanan, Universitas Hasanuddin

${ }^{4}$ Global Cooperation Institute for Sustainable Cities, Yokohama City University, Japan

${ }^{5}$ Universiti Sains Malaysia, Penang, Malaysia
} 


\section{METHOD}

\section{Research Object}

The research object are located along Makassar's coastline and separated by district administrative area. The location map is shown in Figure 1.

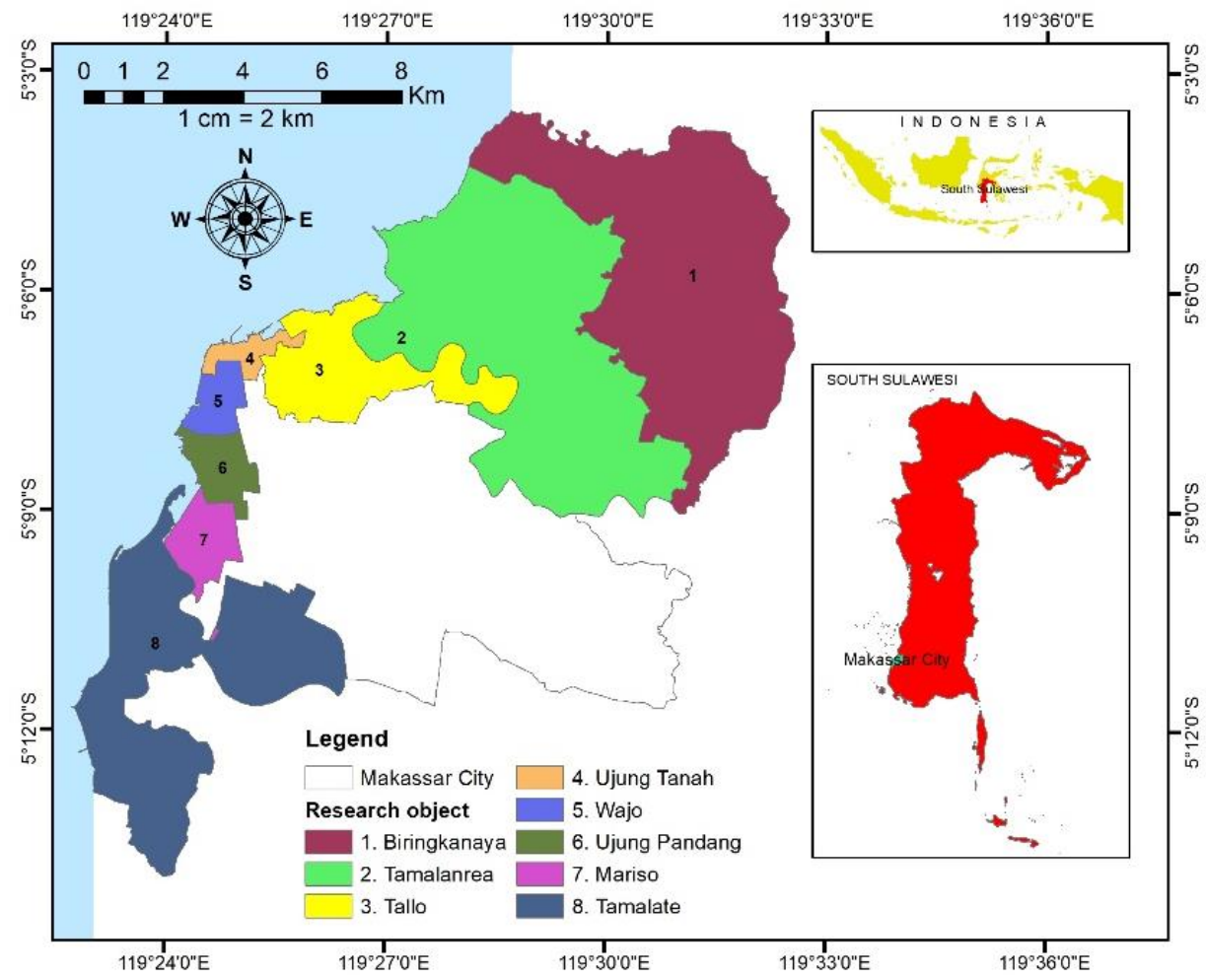

Figure 1. Research object

\section{Land Use Land Cover (LULC)}

Spatial analysis is very helpful in land use change compared with spatial plan which can be used in spatial controlling. Land use projection is used to predict land use in the future by using current land use (Kurnianti, Rustiadi, 2016).

The basic map used to predict land use was 2017 land use and land cover map shown in Figure 2.

\section{Population of Makassar City}

The population of Makassar based population projections for 2015 was 1,449,401, consisting of 717,047 males and 732,354 females. Compared with the population in 2014, the population growth of Makassar was 1.41 percent. The male population grew by 1.45 percent and the female population grew by 1.37 percent (Abdul Hafid, 2016).

Table 1 shows total population and population growth of every sub-district in the research object. The data was used to analyze the prediction of land use and land cover change in 2050. The average population growth is representation of population data of Makassar in 2000-2002 and 2013-2015. 


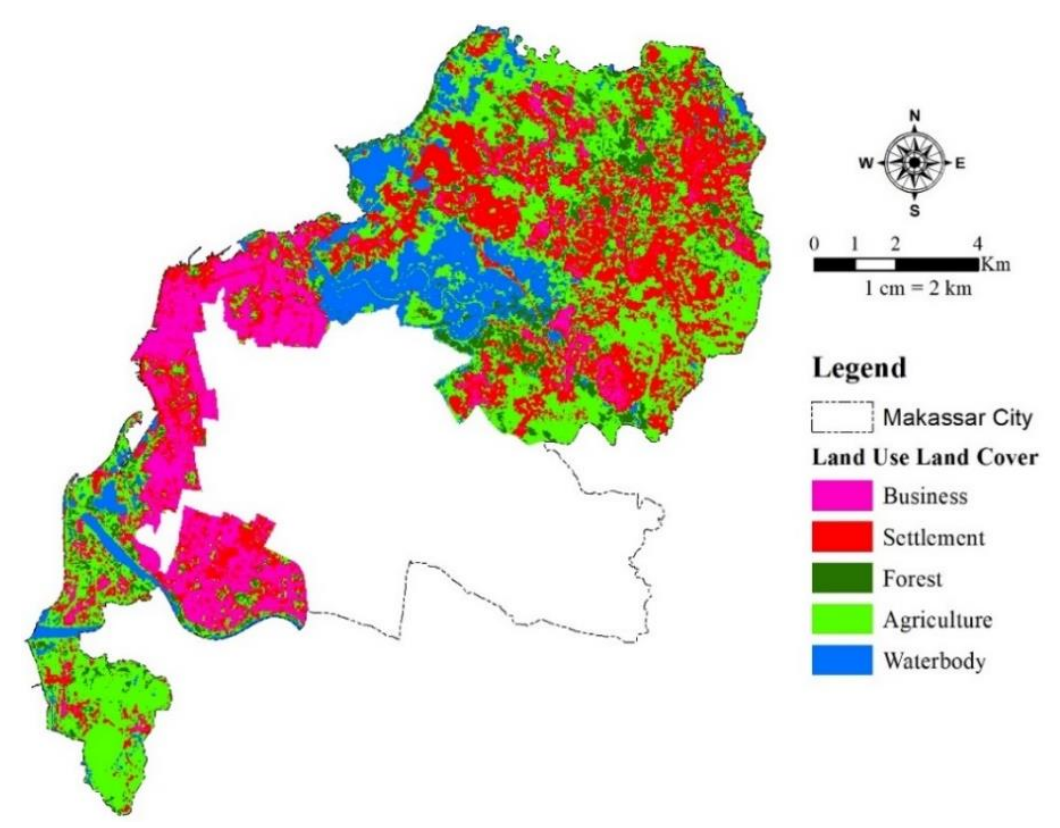

Figure 2. Land Use Land Cover (LULC), Year 2017

Table 1. Population of Makassar City

\begin{tabular}{|c|c|c|c|c|c|c|c|c|c|}
\hline \multirow{2}{*}{$\begin{array}{l}\text { Sub } \\
\text { Districts }\end{array}$} & \multicolumn{6}{|c|}{ Population (year) } & \multicolumn{2}{|c|}{$\begin{array}{l}\text { Population } \\
\text { Growth (\%) }\end{array}$} & \multirow{2}{*}{$\begin{array}{l}\text { Growth } \\
\text { Average } \\
(\%)\end{array}$} \\
\hline & 2000 & 2001 & 2002 & 2013 & 2014 & 2015 & $\begin{array}{l}2000- \\
2002\end{array}$ & $\begin{array}{l}2013- \\
2015\end{array}$ & \\
\hline $\begin{array}{l}\text { Biring } \\
\text { Kanaya }\end{array}$ & 96,057 & 97,951 & 100,018 & 185,030 & 190,829 & 196,612 & 2.04 & 3.08 & 2.56 \\
\hline $\begin{array}{l}\text { Tamalanr } \\
\text { ea }\end{array}$ & 82,641 & 83,873 & 85,140 & 108,024 & 109,471 & 110,826 & 1.50 & 1.29 & 1.40 \\
\hline Tallo & 116,633 & 118,871 & 120,786 & 137,260 & 137,977 & 138,598 & 1.76 & 0.49 & 1.13 \\
\hline $\begin{array}{l}\text { Ujung } \\
\text { Tanah }\end{array}$ & 44,373 & 45,272 & 46,129 & 48,133 & 48,531 & 48,882 & 1.96 & 0.78 & 1.37 \\
\hline Wajo & 34,833 & 35,055 & 35,402 & 30,258 & 30,505 & 30,722 & 0.81 & 0.76 & 0.79 \\
\hline $\begin{array}{l}\text { Ujung } \\
\text { Pandang }\end{array}$ & 27,254 & 28,523 & 29,889 & 27,802 & 28,053 & 28,278 & 4.72 & 0.85 & 2.79 \\
\hline Mariso & 51,491 & 52,411 & 53,282 & 57,790 & 58,327 & 58,815 & 1.72 & 0.88 & 1.30 \\
\hline Tamalate & 130,777 & 131,871 & 133,119 & 183,039 & 186,921 & 190,694 & 0.89 & 2.07 & 1.48 \\
\hline
\end{tabular}

Source: BPS Kota Makassar (Statistics of Makassar City), year 2002 and 2016

\section{Analysis Technique}

Netlogo, is a program developed by Uri Wilensky which is available for free on https://ccl.northwestern.edu/netlogo/ (Bata, 2012). NetLogo is a multi-agent programming language and modeling environment for simulating natural and social phenomena. It is particularly suitable for modeling complex systems which evolve over time. Modelers can give instructions to hundreds or thousands of independent "agents" operating concurrently. This makes it possible to explore connections between micro-level behaviors of individuals and macro-level patterns that emerge from their interactions (Tisue \& Wilensky, 2004). 
Agent Based Models (ABMs) is a relatively new approach to modeling systems composed of autonomous, interacting agents. Agent-based modeling is a way to model the dynamics of complex systems and complex adaptive systems. Such systems are often selforganize and create emergent order. Agent-based models also include models of behavior (human or otherwise) and are used to observe the collective effects of agent behaviors and interactions. The development of agent modeling tools, the availability of micro-data, and advances in computation have made possible a growing number of agent-based applications across a variety of domains and disciplines (MacAl \& North, 2010). A typical agent-based model has three elements:

1. A set of agents, their attributes and behaviors;

2. A set of agent relationships and methods of interaction: An underlying topology of connectedness defines how and with whom agents interact.

3. The agents' environment: Agents interact with their environment in addition to other agents.

A model developer must identify, model, and program these elements to create an agent-based model. The structure of a typical agent-based model is shown in Figure 3.

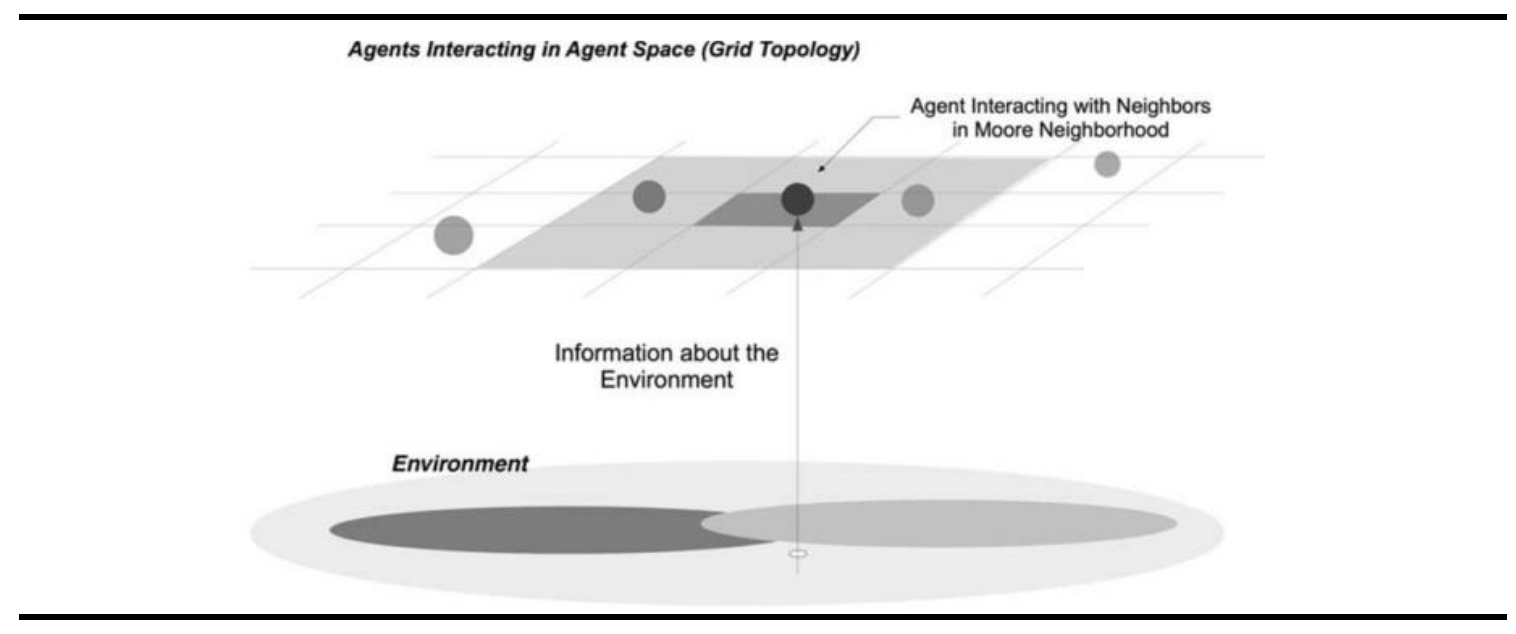

Figure 3. The Structure of A Typical Agent-Based Model

Interacting agents, Other agent interaction topologies are commonly used for modeling agent interactions (Figure 4). In the CA model, agents move from cell to cell in a grid and no more than a single agent occupies one cell at a time. The von Neumann ' 5 neighbour' neighborhood is shown in (Figure 4a); the Moore '9-neighbour' neighborhood is also common. In the Euclidean space model, agents roam in two, three or higher dimensional spaces (Figure $4 \mathrm{~b}$ ). Networks allow an agent's neighborhood to be defined more generally. For network topology, networks may be static or dynamic (Figure 4c). In static networks, links are pre-specified and do not change. For dynamic networks, links and possibly nodes are determined endogenously according to the mechanisms programmed in the models. In the geographic information system (GIS) topology, agents move from patch to patch over a realistic geo-spatial landscape (Figure 4d). In the 'soup' or a spatial model, agents have no location because it is not important (Figure 4e). This study used a Moore neighborhood with '9-neighbour'.

Program code, NetLogo uses procedure to regulate the behaviors of each agent (Bata, 2012). The Code tab is where the code for the model is stored. Commands user wants to use immediately are in the Command Center; commands user wants to save and use later many 
times are found in the Code tab (Wilensky, 1999). The program code of this study is presented in Figure 5.

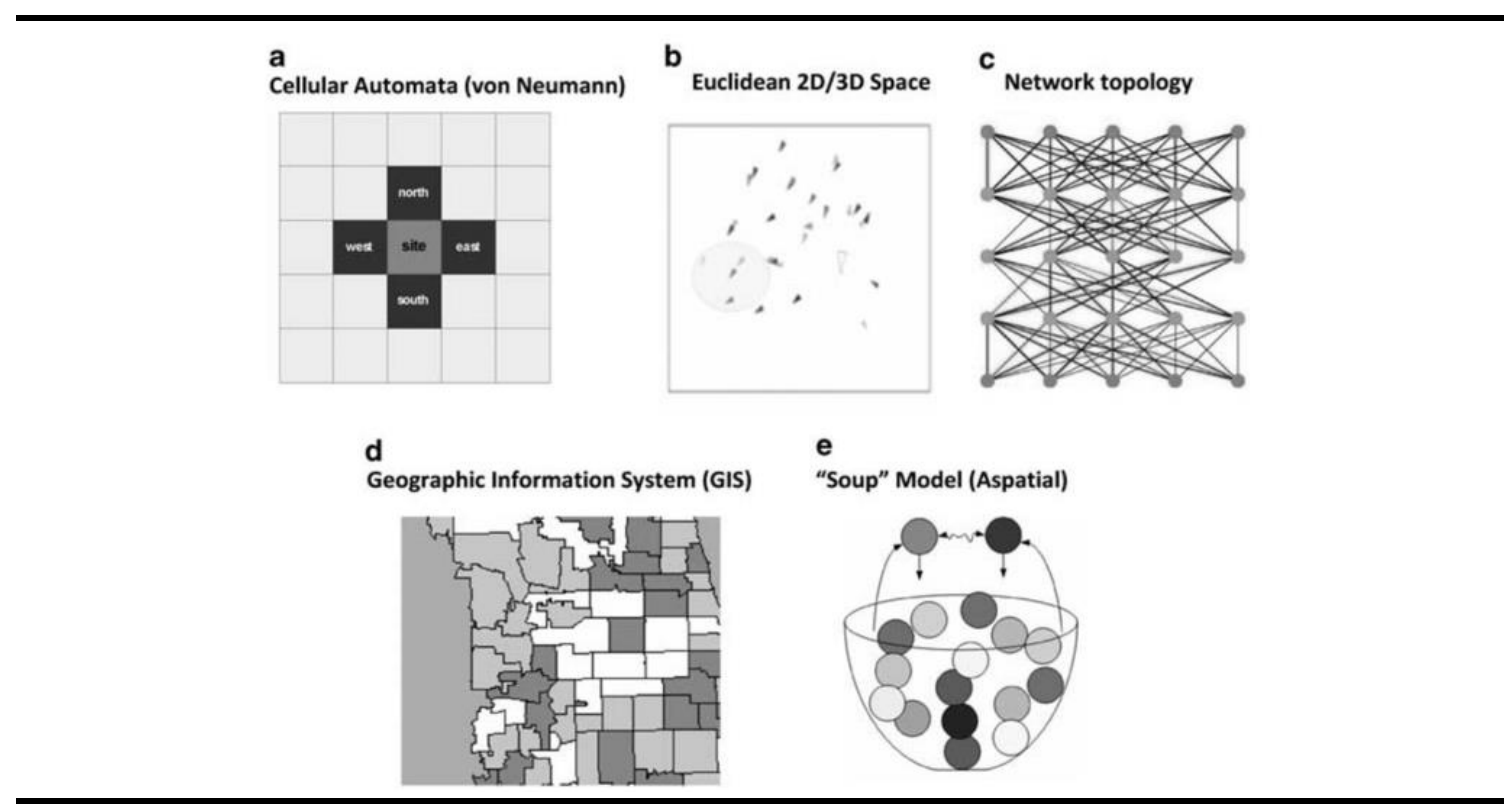

Figure 4. Topologies of Agent Relationships and Social Interaction

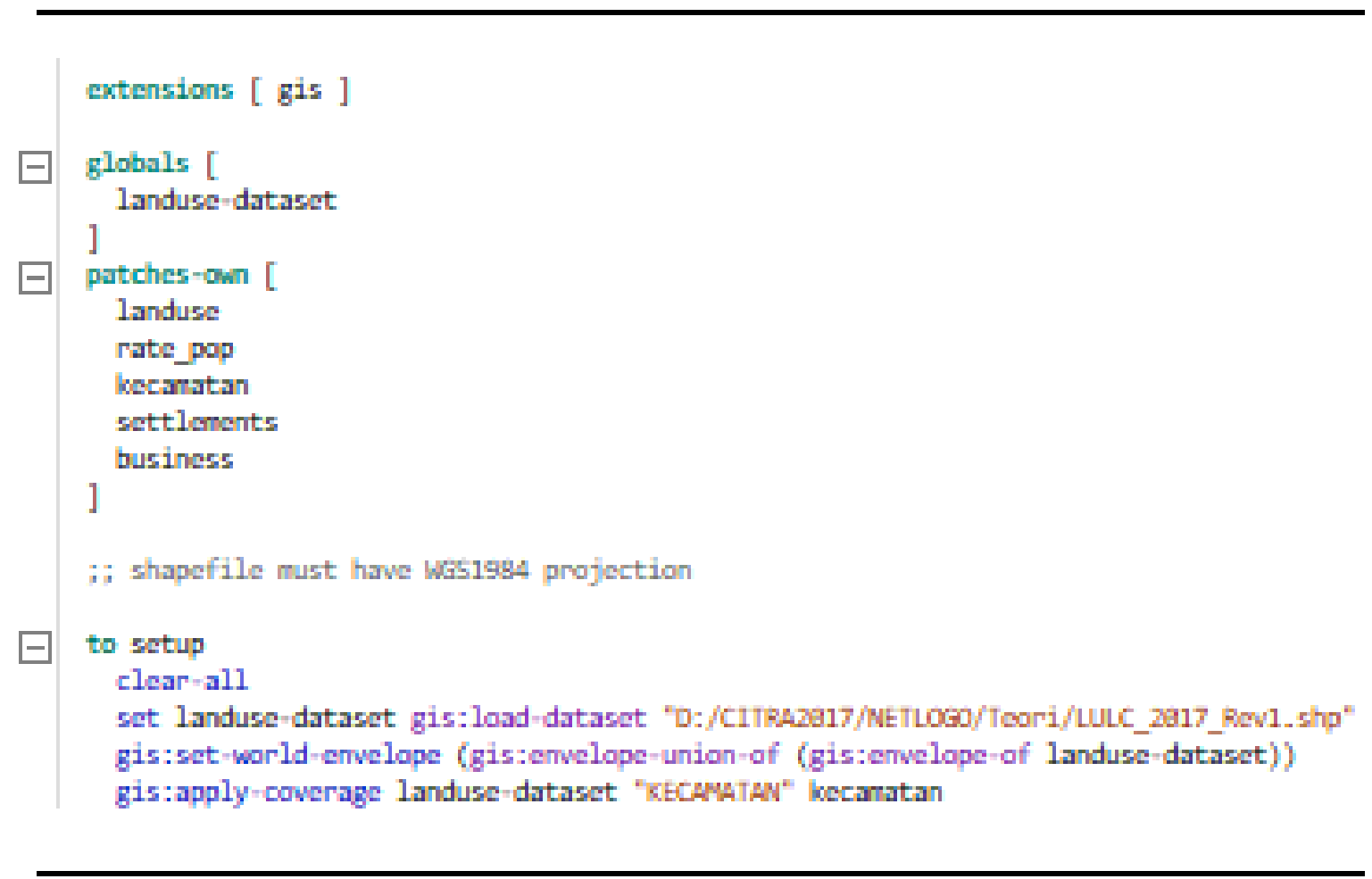

Figure 5. Agent Defining Program Code 


\section{RESULTS AND DISCUSSION}

The analysis result showed change of land use and land cover in every class, i.e. Business, Settlement, Forest, Agriculture, and Water Body. The maps of the change are thematically shown in Figures 6 and 7.

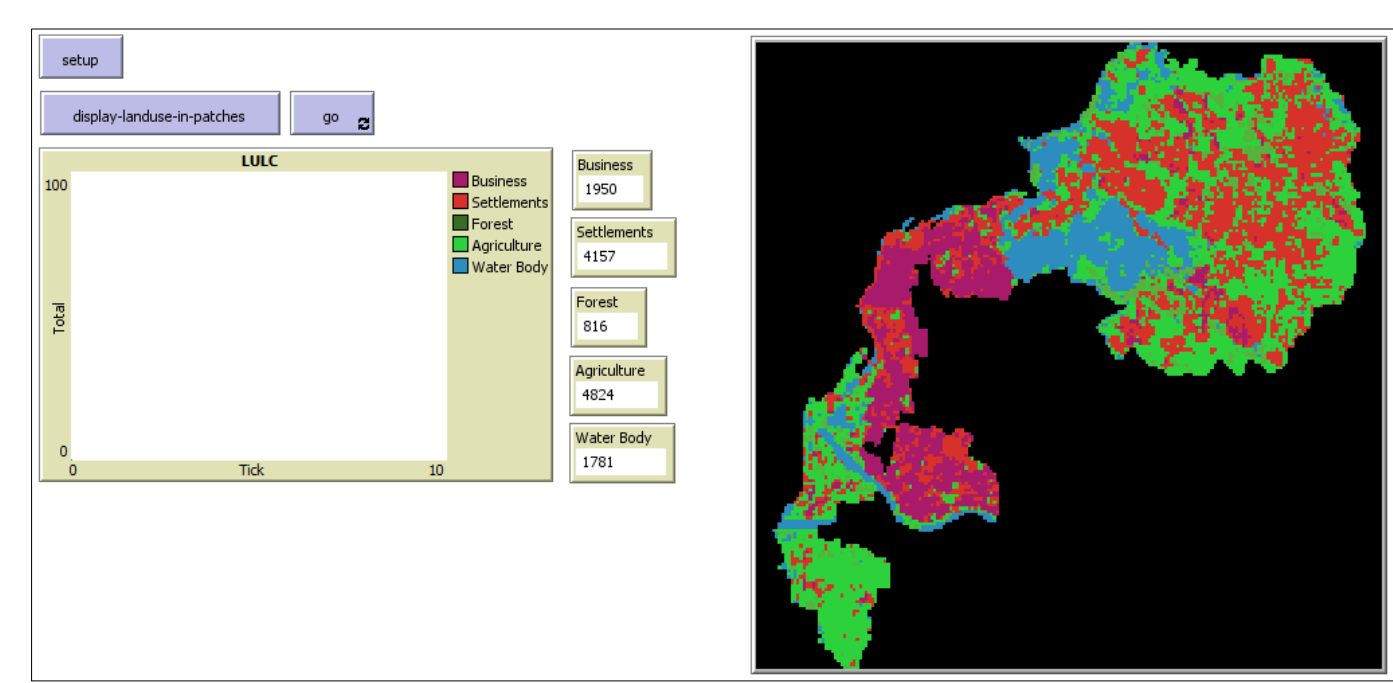

Figure 6. Land use Land Cover (LULC), Year 2017

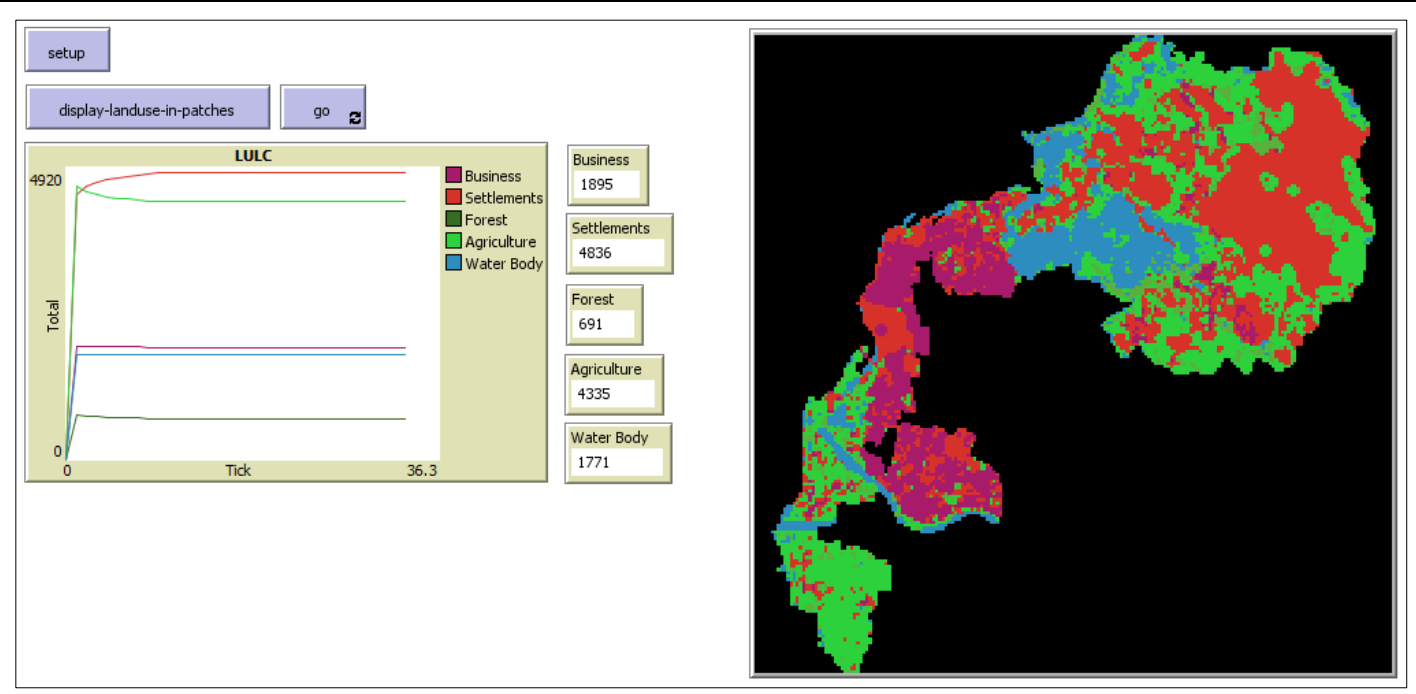

Figure 6. Land use Land Cover (LULC), Year 2050

Table 2 shows the changes of land use and land cover in 2017 to 2050 quantitatively. In the present study, the parameter used to predict changes of land use and land cover was population growth. Additionally, parameters such as distance from accessibility, existing land use, distance from river, distance from activity centers and slope can be used as independent variables to predict land use and land cover changes (Setiady, 2016; Wijaya, 2013). 
Table 2. Data of Land Use and Land Cover Prediction

\begin{tabular}{|c|c|c|c|c|c|c|}
\hline \multirow[b]{2}{*}{ Classification } & \multicolumn{2}{|c|}{ Pixel amount } & \multicolumn{2}{|c|}{ Area (Ha) } & \multirow{2}{*}{$\begin{array}{c}\text { LULC } \\
\text { Change } \\
(\mathrm{Ha})\end{array}$} & \multirow[b]{2}{*}{ Information } \\
\hline & $\begin{array}{c}\text { LULC } \\
2017\end{array}$ & $\begin{array}{c}\text { LULC } \\
2050\end{array}$ & $\begin{array}{c}\text { LULC } \\
2017 \\
\end{array}$ & $\begin{array}{c}\text { LULC } \\
2050\end{array}$ & & \\
\hline Business & 1,950 & 1,895 & $1,708.01$ & $1,659.83$ & -48.17 & Reduced \\
\hline Settlement & 4,157 & 4,836 & $3,641.12$ & $4,235.85$ & 594.74 & Increases \\
\hline Forest & 816 & 691 & 714.73 & 605.25 & -109.49 & Reduced \\
\hline Agriculture & 4,824 & 4,335 & $4,225.34$ & $3,797.03$ & -428.32 & Reduced \\
\hline Water Body & 1,781 & 1,771 & $1,559.98$ & $1,551.22$ & -8.76 & Reduced \\
\hline Total & 13,528 & 13,528 & $11,849.18$ & $11,849.18$ & & \\
\hline
\end{tabular}

\section{CONCLUSION}

The prediction of land use and land cover changes was performed by Agent Based Model (ABM) integrated to NetLogo application. The analysis result showed that in $2017-$ 2050 (33 years), there is increase in Settlement land use by 594.74 hectares, while land uses and land covers which decrease are Business class by 48.17 hectares, Forest 109.49 hectare, Agriculture 428.32 hectares and Water Body 8.76 hectares.

\section{ACKNOWLEDGEMENT}

The authors would like to thank ESRI Indonesia for providing ArcGis 10.5 software to support the implementation of this research. The entire GCI Bureau of Japan, Professor and staff have provided excellent lessons and good facilities.

\section{REFERENCES}

Abdul Hafid. (2016). Kota Makassar dalam Angka 2016. Makassar: BPS Kota Makassar.

Anwar Haris. (2002). Makassar Dalam Angka 2002. Makassar: BPS Kota Makassar.

Bata. (2012). Simulasi Berbasis Agen-Based Modeling (ABM) Menggunakan Netlogo. In SENTIKA 2012. Yogyakarta.

Dhartaredjasa, I. (2013). Analisis citra satelit multitemporal untuk kajian perubahan penggunaan lahan di kota surabaya, kabupaten gresik dan sidoarjo tahun 1994-2012. Jurnal Bumi Indonesia, 2, 164-173.

Fatichah, Rahman, A. (2017). Pemodelan Epidemik Menggunakan Cellular Automata. Retrieved from https://www.researchgate.net/publication/265751686_PEMODELAN_EPIDEMIK_MENGGUNAKAN_ CELLULAR_AUTOMATA

Kurnianti, Rustiadi, B. (2016). Land Use Projection for Spatial Plan Consistency in Jabodetabek. Indonesian Journal of Geography, 47, 124-131.

MacAl, C. M., \& North, M. J. (2010). Tutorial on agent-based modelling and simulation. Journal of Simulation, 4(3), 151-162. https://doi.org/10.1057/jos.2010.3

Setiady, D. (2016). Prediksi Perubahan Lahan Pertanian Sawah Sebagian Kabupaten Klaten dan Sekitarnya Menggunakan Cellular Automata dan Data Penginderaan Jauh. Jurnal Bumi Indonesia, 5.

Tisue, S., \& Wilensky, U. (2004). Netlogo: A Simple Environment for Modeling Complexity. Conference on Complex Systems, 1-10. https://doi.org/10.1109/ICVD.2004.1261037

Wijaya, S. (2013). Integrasi Model Spasial Cellular Automata dan Regresi Logistik Biner untuk Pemodelan Dinamika Perkembangan Lahan Terbangun. Jurnal Bumi Indonesia, 2, 126-133.

Wilensky. (1999). NetLogo. Retrieved November 1, 2017, from http://ccl.northwestern.edu/netlogo/index.shtml

Zope, Eldho, J. (2016). Impacts of land use-land cover change and urbanization on flooding: A case study of Oshiwara River Basin in Mumbai, India. Catena, 145, 142-154. https://doi.org/10.1016/j.catena.2016.06.009. 